\title{
A critical analysis of test-retest reliability in instrument validation studies of cancer patients under palliative care: a systematic review
}

\author{
Carlos Eduardo Paiva ${ }^{1,2,3^{*}}$, Eliane Marçon Barroso ${ }^{2}$, Estela Cristina Carneseca ${ }^{2,3}$, Cristiano de Pádua Souza ${ }^{1}$,
} Felipe Thomé dos Santos ${ }^{1}$, Rossana Verónica Mendoza López ${ }^{3}$ and Bianca Sakamoto Ribeiro Paiva ${ }^{2,3}$

\begin{abstract}
Background: Patient-reported outcome validation needs to achieve validity and reliability standards. Among reliability analysis parameters, test-retest reliability is an important psychometric property. Retested patients must be in a clinically stable condition. This is particularly problematic in palliative care (PC) settings because advanced cancer patients are prone to a faster rate of clinical deterioration. The aim of this study was to evaluate the methods by which multi-symptom and health-related qualities of life (HRQOL) based on patient-reported outcomes (PROs) have been validated in oncological PC settings with regards to test-retest reliability.

Methods: A systematic search of PubMed (1966 to June 2013), EMBASE (1980 to June 2013), Psychlnfo (1806 to June 2013), CINAHL (1980 to June 2013), and SCIELO (1998 to June 2013), and specific PRO databases was performed. Studies were included if they described a set of validation studies. Studies were included if they described a set of validation studies for an instrument developed to measure multi-symptom or multidimensional HRQoL in advanced cancer patients under PC. The COSMIN checklist was used to rate the methodological quality of the study designs.

Results: We identified 89 validation studies from 746 potentially relevant articles. From those 89 articles, 31 measured test-retest reliability and were included in this review. Upon critical analysis of the overall quality of the criteria used to determine the test-retest reliability, 6 (19.4\%), 17 (54.8\%), and $8(25.8 \%)$ of these articles were rated as good, fair, or poor, respectively, and no article was classified as excellent. Multi-symptom instruments were retested over a shortened interval when compared to the HRQoL instruments (median values 24 hours and 168 hours, respectively; $\mathrm{p}=0.001$ ). Validation studies that included objective confirmation of clinical stability in their design yielded better results for the test-retest analysis with regard to both pain and global HRQoL scores $(p<0.05)$. The quality of the statistical analysis and its description were of great concern.

Conclusion: Test-retest reliability has been infrequently and poorly evaluated. The confirmation of clinical stability was an important factor in our analysis, and we suggest that special attention be focused on clinical stability when designing a PRO validation study that includes advanced cancer patients under PC.
\end{abstract}

Keywords: Validation studies, Test-retest reliability, Systematic review, Cancer, Palliative care

\footnotetext{
* Correspondence: caredupai@gmail.com

'Department of Clinical Oncology, Barretos Cancer Hospital, Barretos

São Paulo CEP 14784-400, Brazil

${ }^{2}$ Palliative Care and Quality of Life Research Group, Post-Graduate Program,

Barretos Cancer Hospital, Barretos, São Paulo, Brazil

Full list of author information is available at the end of the article
}

C Biomed Central

(c) 2014 Paiva et al.; licensee BioMed Central Ltd. This is an Open Access article distributed under the terms of the Creative Commons Attribution License (http://creativecommons.org/licenses/by/2.0), which permits unrestricted use, distribution, and reproduction in any medium, provided the original work is properly cited. The Creative Commons Public Domain Dedication waiver (http://creativecommons.org/publicdomain/zero/1.0/) applies to the data made available in this article, unless otherwise stated. 


\section{Background}

Advanced cancer patients under palliative care (PC) experience many physical, psychosocial, and existential problems [1]. The PC team is essential for the screening, diagnosis, and treatment of cancer symptoms with the aim of improving the patients' health-related quality of life (HRQoL). Therefore, an ideal assessment of symptoms and HRQoL should be performed using validated patient-reported outcome (PRO) instruments [2].

The process of PRO validation requires time and includes rigorous methods of data analysis. It encompasses the translation of foreign languages, cultural adaptation, and the evaluation of psychometric properties. Overall, a PRO validation needs to achieve the standards of validity and reliability [2]. Among reliability analyses, the most important are internal consistency, inter-rater reliability, and test-retest reliability. Test-retest reliability can be defined as "a measure of the reproducibility of the scale, that is, the ability to provide consistent scores over time in a stable population" [3].

Retested patients must be in a stable condition with respect to the construct to be measured by the PRO. This situation is particularly problematic in PC settings because advanced cancer patients are prone to a faster rate of clinical deterioration [4].

Thus, the aim of the present study was to evaluate the method by which multi-symptom and HRQoL PROs have been validated in oncological PC settings regarding test-retest reliability.

\section{Methods}

\section{Design}

A systematic literature review was used.

\section{Eligibility criteria}

The studies included in this systematic review met all of the following criteria: (1) validation study of a multidimensional quality of life instrument or a multidimensional symptom assessment instrument; (2) publication in a peer-reviewed journal; and (3) analysis of a population composed mainly of advanced cancer patients undergoing PC (or hospice care, end-of-life care, or some similar type of care).

Studies were excluded for any of the following reasons: (1) the study was not published as a full article (i.e., conference proceedings were excluded); (2) the study contained pediatric data; or (3) the publication was a duplicate publication.

\section{Data sources}

Validation studies of PROs were retrieved from the following online databases: PubMed (1966 to June 2013), EMBASE (1980 to June 2013), PsychInfo (1806 to June 2013), CINAHL (1980 to June 2013), and SCIELO
(1998 to June 2013). The Patient-Reported Outcome and Quality of Life Instrument Database (PROQOLID) [5] (http://www.proqolid.org/) and the Australian Centre on Quality of Life (ACQOL) [6] (http://www.deakin.edu. $\mathrm{au} /$ research/acqol/index.php) were also used to search for validation studies.

\section{Search strategy}

Our search strategies for PubMed included the following: (1) quality of life instruments: (instrument OR questionnaire OR scale OR inventory OR checklist) AND (reliability OR test-retest OR validation OR psychometric* OR retest OR repeatability) AND (cancer OR tumor OR tumour OR carcinoma OR malignancy OR "neoplasms" [MESH]) AND "quality of life" AND (palliative care OR end-of-life OR "end of life" OR hospice OR terminal OR advanced); (2) multiple-symptom instruments: (instrument OR questionnaire OR scale OR inventory OR checklist) AND (reliability OR test-retest OR validation OR psychometric* OR retest OR repeatability) AND (cancer OR tumor OR tumour OR carcinoma OR malignancy OR "neoplasms" [MESH]) AND (symptom OR symptoms) AND (palliative care OR endof-life OR "end of life" OR hospice OR terminal OR advanced). Searches using EMBASE, PsychInfo, CINAHL, and SCIELO were conducted by combining each of the terms used in the PubMed search strategy. With regards to the PROQOLID and ACQOL databases, references were individually screened. To identify additional papers, the reference lists of relevant articles were reviewed by one of the authors (CEP).

\section{Data extraction}

Initial searches (titles and abstracts) were conducted independently by CPS and FT. The studies with full text available were further reviewed, the data were independently extracted by two other reviewers (CEP, CPS), and the data were verified by a third reviewer (BSRP).

A standardized data collection form was used. The data collected included study demographics (year of publication, country in which the study was conducted, language in which the instrument was administered), the name of the instrument, and information about the characteristics of the patients enrolled (age, performance status). We also collected data regarding the statistical methods employed to perform the test-retest analysis, the time frame from test to retest, the total number of patients included in the study, and the number of patients included in the reliability test-retest analysis. If the sample size for the test-retest reliability was planned a priori, the study was included only if the article stated that the patient was clinically stable. The following QoL domains were systematically extracted from each article: global, physical, psychological, social, 
existential/spiritual, and functional. With regard to the symptoms, we specifically analyzed the pain, fatigue, nausea, anxiety, and depression domains.

\section{Analytic approach}

The COSMIN (COnsensus-based Standards for selection of health Measurement INstruments) checklist [7] was used to rate the methodological quality of the study designs. Because our focus was test-retest reliability, only the COSMIN Box B (reliability) was used. The "worst score counts" algorithm was used for the analysis [8]. Briefly, each item from COSMIN Box B was rated individually as "excellent", "good", "fair", or "poor", and an overall score was given by taking the lowest score of any of the items.

Because different statistical methods were used in many of the studies, a robust meta-analysis of the data was not possible. Therefore, to perform a pooled analysis, we followed the method of Terwee et al. [9] and accepted a minimum reliability threshold of 0.70 as a measure of "adequate test-retest results". Each extracted domain was classified as the number of articles with test-retest values $\geq 0.70$. The number of adequate testretest results was associated with the evaluated outcome (HRQoL versus symptoms) and with the evidence provided for clinical stability, as measured by item 7 of COSMIN Box B. For this analysis, a chi-square test for linear trend was used. In addition, the time (in hours) to retest was compared between groups with adequate and non-adequate test-retest results using the Mann-Whitney $U$ Test. Data are presented as median values and percentiles of 25 (P25) and 75 (P75).

The PRISMA (Preferred Reporting Items for Systematic Reviews and Meta-Analyses) guidelines for building reviews were followed during the preparation of this review (see the PRISMA checklist in the Supplementary file).

\section{Results}

Figure 1 summarizes the identification and selection of studies. We identified 89 articles describing validation studies of PRO that evaluated advanced cancer patients under PC. Of those, 31 (34.8\%) measured test-retest reliability. Information from the included studies is detailed in Table 1.

\section{Methodological quality of the studies}

Two authors (CEP, EMB) classified the articles according to the COSMIN guidelines; the percentage of agreement between coders was $85.3 \%$ (Cohen's Kappa coefficient = $0.764)$. Any disagreements in interpretation were resolved by a discussion with a third author (BSRP). There were 4 (12.9\%) [11,25,28,40], 17 (54.8\%) [10,12-15,18,20,24,26,27, $30-32,34,36-38]$, and 10 (32.2\%) [16,17,19,21-23,29,33,35,39] articles classified as good, fair, and poor, respectively, with regards to the overall quality criteria. No article was classified as excellent according to the aforementioned criteria. The global quality classification per item is described in Figure 2.

\section{Sample sizes}

A total of 29 studies (29 of 31; 93.5\%) [10-19,21-23,25-40] described the number of patients submitted to the testretest analysis. Of those, the median (P25-P75) number of patients included was 60 (32-119). The majority of the studies (24 of 29; 82.8\%) [10-12,14-16,18,19,21-23,25-29, $31,32,34-36,38-40]$ included fewer than the total number of patients for the reliability analysis. Overall, 53.8\% (95\% CI 19.6\%-87.9\%) of the total number of analyzed patients were used for the test-retest reliability analysis. Only 2 articles [28,37] described the sample size calculation for the test-retest analysis. One study [35] used a reference from others recommending that at least 50 patients should be used for this type of statistical analysis.

\section{Time to retest}

The time interval to retest was clearly stated in all of the included studies [10-40]. The median (P25-P75) time was 72 (27-168) hours. The median (P25-P75) time intervals for the retest were 24 (3.25-60) hours and 168 (48-204) hours for the symptom and HRQoL validation studies, respectively $(\mathrm{p}=0.001)$.

\section{Confirmation of clinical stability}

Of the 31 analyzed articles, 10 (10 of 31, 32.3\%) [11-15,20,21,26,36,38] clearly stated that only clinically stable patients were submitted to the retest. The confirmation of clinical stability in accordance with the COSMIN checklist was associated with adequate results for the testretest analysis regarding both pain and global HRQoL scores $(\mathrm{p}<0.05$, Table 2$)$. Of those studies, 6 used 1 or more of the following objective criteria to define a stable condition: patient perception of change $(n=2)[11,20]$; stable doses of opiates $(n=1)$ [36] or lack of a new medication for symptom treatment $(n=2)[14,38]$; emergency department visit and/or hospitalization $(n=1)$ [14]; and change in Performance Status or in daily living activities $(\mathrm{n}=1)[12]$.

\section{Scores of retest}

In the present review, we chose to perform statistical comparisons only for the pain and global HRQoL scores because they were the most commonly described domains in the selected studies (Table 3). Taking into consideration a set value of $\geq 0.70$ as an adequate result in the test-retest analysis, $50 \%$ (9 of $18,50 \%$ ) [13,20,25,29,32,35-38] and $45 \%$ (9 of $20,45 \%$ ) [10-12,18,23-25,32,40] of the studies with pain and global HRQoL values, respectively, were considered adequate. 


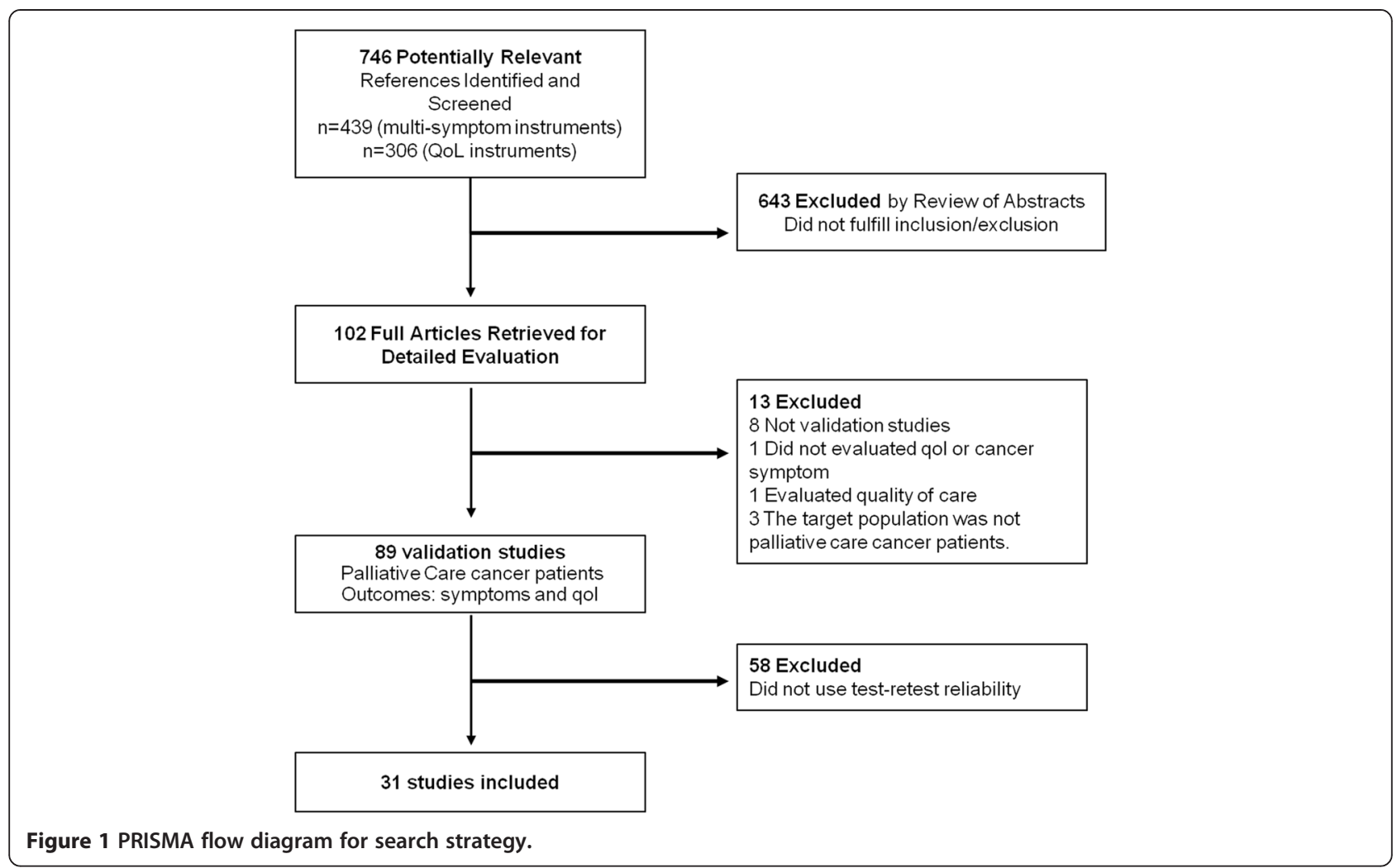

There was a non-significant trend favoring shorter time intervals for the retest in the studies with adequate results for the retest statistical analysis (value $\geq 0.70$ ) in comparison with those with non-satisfactory results (value <0.70) (Table 4).

Three studies $[18,29,40]$ compared 2 different time frame intervals for the retest. Two of them $[18,40]$ measured global HRQoL 3 hours and 7 days after the first evaluation; the test-retest results were 0.84-0.93 and 0.63 at 3 hours and 7 days, respectively. The other validation study [29] evaluated cancer symptoms using the Edmonton Symptom Assessment System (ESAS) scale. That study found higher test-retest values for shorter time intervals, with the exception of the symptom of fatigue (Table 5).

\section{Statistical methods used}

Of those instruments with continuous scores $(\mathrm{n}=29), 11$ (11 of $29,37.9 \%)$ [11,12,14,18,20,23,25,28,31,38,40] evaluated the test-retest reliability using the intraclass correlation coefficient, and 14 (14 of $29,48.3 \%$ ) [10,13,15, $17,24,27,29,30,32,34-37,39]$ performed some type of correlation analysis such as Spearman's $(n=6)$ or Pearson's $(n=8)$ test. Interestingly, for those studies in which the intraclass correlation coefficient (ICC) method was used, none described the statistical model or formula used; therefore, no study could be classified as "excellent" according to item 11 in Box B of the COSMIN guidelines. Two studies used paired analysis (repeated measures of analysis of variance [ANOVA], $\mathrm{n}=1$; paired $t$ test, $\mathrm{n}=1)$ to evaluate test-retest reliability $[16,33]$. Three studies with ordinal score instruments calculated the weighted kappa statistic $[20,21,26]$. Two studies did not describe the type of statistics used [19,22].

\section{Discussion}

In this study, we investigated the methods by which validation studies of PRO have been performed in the PC setting, particularly with regards to test-retest reliability. In general, the methodological quality of this psychometric property was investigated poorly to fairly; according to the COSMIN checklist, only $12.3 \%$ of the studies were considered of good quality, and none were considered of excellent quality. In addition, we highlighted the importance of verifying the clinical stability of advanced cancer patients before performing the retest. Based on our results, clinical stability is even more important for testretest reliability than the accurate definition of the time interval at which the retest is performed.

In our review, we identified 89 validation studies that included cancer symptoms and/or HRQoL as outcome variables. Of those, only $31(34.8 \%)$ evaluated the testretest reliability. As the test-retest reliability is an essential psychometric property to be measured in validation 
Table 1 Instruments developed to assess symptoms or quality of life of cancer patients under palliative care

\begin{tabular}{|c|c|c|c|c|c|c|c|c|c|}
\hline \multirow[t]{2}{*}{ Author } & \multirow{2}{*}{$\begin{array}{l}\text { Country } \\
\text { (language) }\end{array}$} & \multirow[t]{2}{*}{ Instrument } & \multirow{2}{*}{$\begin{array}{l}\text { No. of } \\
\text { items }\end{array}$} & \multirow[t]{2}{*}{ Population profile } & \multicolumn{2}{|c|}{ Sample } & \multirow{2}{*}{$\begin{array}{l}\text { Time to } \\
\text { retest }\end{array}$} & \multirow{2}{*}{$\begin{array}{c}\text { Objective } \\
\text { confirmation } \\
\text { of clinical stability }\end{array}$} & \multirow{2}{*}{$\begin{array}{c}\text { Type of } \\
\text { statistics used }\end{array}$} \\
\hline & & & & & $\begin{array}{l}\mathrm{n} \\
\text { (total) }\end{array}$ & $\mathrm{n}$ (retest) & & & \\
\hline $\begin{array}{l}\text { Axelsson } \\
\text { et al. [10] }\end{array}$ & $\begin{array}{l}\text { Sweden } \\
\text { (Swedish) }\end{array}$ & AQEL & 22 & $\begin{array}{l}\text { ACP. Median age }=67.5 \text { years, } \\
\text { mean and median } \mathrm{KPS}=62.3 \\
\text { and } 70 \text {, respectively. }\end{array}$ & 71 & 30 & 3 days & Not described & Spearman Rank correlation \\
\hline $\begin{array}{l}\text { Cohen } \\
\text { et al. [11] }\end{array}$ & Canada (English) & MQOL & 16 & $\begin{array}{l}\text { ACP. Could be receiving } \\
\text { chemotherapy. Mean age: } \\
59 \text { years). Life expectancy } \\
\text { greater than } 2 \text { weeks. }\end{array}$ & 100 & $49-59$ & 2 days & Yes & ICC \\
\hline $\begin{array}{l}\text { Llobera } \\
\text { et al. [12] }\end{array}$ & Spain (Spanish) & HRCA-QL index & 5 & $\begin{array}{l}\text { APC (end-of-life). Median } \\
\text { survival }=59 \text { days. }\end{array}$ & 200 & 39 & $\begin{array}{l}1 \text { month } \\
\text { (mean) }\end{array}$ & Yes & ICC \\
\hline $\begin{array}{l}\text { Mystakidou } \\
\text { et al. [13] }\end{array}$ & Greece (Hellenic) & PLQ & 28 & $\begin{array}{c}\text { Patients with symptomatic } \\
\text { incurable cancer. Off anticancer } \\
\text { treatment for } \geq 3 \text { months. All } \\
\text { patients classified as ECOG-PS } \geq 2 \\
\text { (ECOG-PS3 }=68 \%) .\end{array}$ & 120 & 120 & 7 days & No & Spearman Rank correlation \\
\hline $\begin{array}{l}\text { Steinhauser } \\
\text { et al. [14] }\end{array}$ & USA (English) & QUAL-E & 25 & $\begin{array}{c}\text { Terminal CHF, ESRD, COPD, and } \\
\text { stage IV cancer ( } 56 \%) \text {. }\end{array}$ & 248 & $135-170$ & 7 days & Yes & ICC \\
\hline $\begin{array}{l}\text { Lopes Ferreira } \\
\text { et al. [15] }\end{array}$ & $\begin{array}{c}\text { Portugal } \\
\text { (Portuguese) }\end{array}$ & POS & 10 & $\begin{array}{l}\text { ACP (life expectancy }<1 \text { year), } \\
\text { non-terminal, many of them } \\
\text { undergoing chemotherapy. }\end{array}$ & 109 & 30 & 7 days & No & Pearson correlation \\
\hline $\begin{array}{l}\text { Suárez-del-Real } \\
\text { et al. [16] }\end{array}$ & Mexico (Spanish) & QLQ-C15-PAL & 15 & $\begin{array}{c}\text { ACP undergoing exclusive palliative } \\
\text { care. } \mathrm{KPS}<=70 \%=78 \% .\end{array}$ & 83 & 30 & $\begin{array}{l}15.7 \text { days } \\
\text { (mean) }\end{array}$ & No & $\begin{array}{l}\text { Repeated measures } \\
\text { ANOVA }\end{array}$ \\
\hline $\begin{array}{l}\text { Leppert } \\
\text { et al. [17] }\end{array}$ & Poland (Polish) & QLQ-C15-PAL & 15 & ACP undergoing palliative care. & 129 & 129 & 7 days & No & Spearman Rank correlation \\
\hline Kim et al. [18] & Korea (Korean) & MQLS & 32 & $\begin{array}{l}\text { Mortality rate during study }=80 \% \\
\qquad \text { ECOG-PS }>=3=71.2 \%\end{array}$ & 70 & $54-64$ & $\begin{array}{l}3 \text { hours and } \\
7 \text { days }\end{array}$ & No & ICC \\
\hline Kim et al. [19] & Korea (Korean) & HQLS & 43 & $\begin{array}{l}\text { Advanced cancer patients under } \\
\text { exclusive palliative care. } \\
\text { ECOG-PS3/4 =64.2\%. }\end{array}$ & 180 & 88 & 1-2 weeks & No & Not described \\
\hline $\begin{array}{l}\text { Serra-Prat } \\
\text { et al. [20] }\end{array}$ & Spain (Spanish) & POS & 10 & $\begin{array}{l}\text { ACP under palliative care. Mean } \\
\qquad \mathrm{KPS}=50.93 \% .\end{array}$ & 200 & $\begin{array}{c}\text { Not } \\
\text { described }\end{array}$ & 1 week & Yes & ICC \\
\hline $\begin{array}{l}\text { Eisenchlas } \\
\text { et al. [21] }\end{array}$ & $\begin{array}{l}\text { Argentina } \\
\text { (Spanish) }\end{array}$ & POS & 10 & $\begin{array}{l}\text { ACP under palliative care. ECOG-PS } \\
\qquad 3 / 4=58 \% .\end{array}$ & 65 & 24 & 2 days & No & $\begin{array}{l}\text { Weighted kappa } \\
\text { agreement }\end{array}$ \\
\hline Guo et al. [22] & USA (English) & Brief Hospice Inventory & 17 & $\begin{array}{l}\text { Geriatric population (mean age }= \\
78 \text { years, } 83 \% \geq 70 \text { years) } 47 \% \text { Advanced } \\
\text { cancer under hospice care in } 47 \% \text {. }\end{array}$ & 145 & 63 & 1 week & No & Not described \\
\hline Lo et al. [23] & China (Chinese) & MQOL & 16 & Incurable ACP. & 462 & 20 & 2 days & No & ICC \\
\hline Shahidi et al. [24] & Iran (Persian) & MQOL & 16 & $\begin{array}{c}\text { Mean KPS }=74.8 \% \text {. Any type of } \\
\text { incurable cancer with an estimated } \\
\text { life expectancy of }<12 \text { months was } \\
\text { considered for the study. }\end{array}$ & 61 & $\begin{array}{l}\text { Not clearly } \\
\text { stated }\end{array}$ & 24-72 hours & No & Pearson correlation \\
\hline
\end{tabular}


Table 1 Instruments developed to assess symptoms or quality of life of cancer patients under palliative care (Continued)

\begin{tabular}{|c|c|c|c|c|c|c|c|c|c|}
\hline Harding et al. [25] & $\begin{array}{l}\text { South Africa and } \\
\text { Uganda (most } \\
\text { spoke IsiZulu') }\end{array}$ & $\begin{array}{l}\text { APCA African } \\
\text { Palliative Outcome Scale }\end{array}$ & 10 & $\begin{array}{l}\text { Hospice patients, including ACP. } \\
\text { Limited self-care and completely } \\
\text { disabled }=41.7 \% \text {. }\end{array}$ & 682 & 307 & $\begin{array}{l}21.2 \text { hours } \\
\text { (mean) }\end{array}$ & No & ICC \\
\hline Hearn et al. [26] & $\begin{array}{l}\text { England and } \\
\text { Scotland (English) }\end{array}$ & POS & 10 & $\begin{array}{l}\text { ACP }(98 \%) \text { under palliative care. } \\
\text { Limited activity or disabled }=47.1 \% \text {. }\end{array}$ & 168 & 34 & 3-7 days & Yes & $\begin{array}{l}\text { Weighted kappa } \\
\text { agreement }\end{array}$ \\
\hline Wilson et al. [27] & Canada (English) & SISC & 13 & $\begin{array}{l}\text { ACP under palliative care. Median } \\
\text { survival = } 46 \text { days. }\end{array}$ & 68 & 46 & $1-3$ days & No & Pearson correlation \\
\hline Agra et al. [28] & Spain (Spanish) & $\mathrm{RSCL}$ & 39 & $\begin{array}{l}\text { ACP under palliative care. Terminal } \\
\text { illness (life expectancy }<6 \text { months). } \\
\text { KPS }<70 \% \text { in } 65.2 \% \text {. }\end{array}$ & 118 & 116 & 24 hours & No & ICC \\
\hline Chang et al. [29] & USA (English) & ESAS & 10 & $\begin{array}{l}\text { ACP under palliative care. Mostly } \\
\text { elderly male patients. }\end{array}$ & 233 & $19-23$ & $\begin{array}{l}1 \text { day and } 1 \\
\text { week }\end{array}$ & No & Spearman Rank correlation \\
\hline Stiel et al. [30] & $\begin{array}{l}\text { Germany } \\
\text { (German) }\end{array}$ & MIDOS & 12 & $\begin{array}{l}\text { ACP under palliative care. ECOG-PS } \\
\qquad 3 / 4=56.6 \%\end{array}$ & 60 & 60 & 1 day & No & Pearson correlation \\
\hline Moro et al. [31] & Italy (Italian) & ESAS & 10 & $\begin{array}{l}\text { ACP under exclusive palliative care. } \\
\text { In-patients, KPS } \leq 40=75 \% \\
\text { Median survival }=35 \text { days. }\end{array}$ & 241 & 60 & 24-48 hours & No & ICC \\
\hline $\begin{array}{l}\text { Mystakidou } \\
\text { et al. [32] }\end{array}$ & Greece (Greek) & MDASI & 19 & $\begin{array}{l}\text { ACP under palliative care. ECOG-PS } \\
\qquad 3 / 4=63 \% .\end{array}$ & 150 & 100 & 3 days & No & Pearson correlation \\
\hline Pautex et al. [33] & Swiss (French) & ESAS & 10 & $\begin{array}{l}\text { ACP under palliative care. Mean } \\
\text { age }=72 \text { years. }\end{array}$ & 42 & 42 & 1 day & No & Paired $t$ test \\
\hline Stiel et al. [34] & $\begin{array}{l}\text { Germany } \\
\text { (German) }\end{array}$ & HOPE-SP-CL & 16 & ACP under palliative care; inpatients. & 31,055 & $332-472$ & 7 days & No & Spearman Rank correlation \\
\hline Carvajal et al. [35] & Spain (Spanish) & ESAS & 10 & $\begin{array}{l}\text { ACP under palliative care. } \\
\text { KPS } \leq 70 \%=45.5 \% \text {. }\end{array}$ & 171 & 146 & $0-6$ hours & No & $\begin{array}{l}\text { Spearman Rank correlation } \\
\text { and Lin's Concordance test }\end{array}$ \\
\hline $\begin{array}{l}\text { Radbruch } \\
\text { et al. [36] }\end{array}$ & $\begin{array}{l}\text { Germany } \\
\text { (German) }\end{array}$ & MIDOS & 12 & $\begin{array}{l}\text { ACP under palliative care. ECOG-PS } \\
\qquad 3 / 4=81.2 \% .\end{array}$ & 128 & 76 & 1-6 days & Yes & Pearson correlation \\
\hline Kwon et al. [37] & Korea (Korean) & ESAS & 10 & $\begin{array}{l}\text { Mostly symptomatic ACP undergoing } \\
\text { active antineoplastic treatment. }\end{array}$ & 162 & 162 & 2-4 hours & No & Pearson correlation \\
\hline Aoun et al. [38] & Australia (English) & SAS & 7 & ACP under palliative care. & 572 & 60 & 2 hours & Yes & ICC \\
\hline Pereira et al. [39] & $\begin{array}{l}\text { Portugal } \\
\text { (Portuguese) }\end{array}$ & FACT-G & 28 & $\begin{array}{c}\text { ACP under PC (end-of-life). Inpatients } \\
\text { and outpatients. Performance status } \\
\text { not described. }\end{array}$ & 346 & 27 & 8-9 days & No & Pearson correlation \\
\hline $\begin{array}{l}\text { Sterkenburg } \\
\text { et al. [40] }\end{array}$ & Canada (English) & MQLS & 32 & $\begin{array}{l}\text { Most were ACP under palliative care. } \\
\text { Mean survival }=49.56 \text { days. }\end{array}$ & 84 & 73 & $\begin{array}{l}3 \text { hours and } \\
7 \text { days }\end{array}$ & No & ICC \\
\hline
\end{tabular}

USA United States of America, ICC intraclass correlation coefficient, CHF chronic heart failure, ANOVA Analysis of variance, ESRD end stage renal disease, COPD chronic obstructive pulmonary disease, AQEL Assessment of Quality of Life at the End of Life, MQOL McGill Quality of Life Questionnaire, HRCA-QL index Hebrew Rehabilitation Centre for Aged Quality of Life Index, PLQI The Palliative Care Quality of Life Instrument, QUAL-E Quality of Life at the End of Life, POS Palliative Care Outcome Scale, QLQ-C15-PAL The European Organization for Research and Treatment of Cancer (EORTC) QLQ-C15-PAL, MQLS MCMaster Quality of Life Scale, HQLS Hospice Quality of Life Scale, SISC Structured Interview for Symptoms and Concerns, RSCL Rotterdam Symptom Check List, ESAS Edmonton Symptom Assessment System, MIDOS Minimal Documentation System, MDASI MD Anderson Symptom Inventory, HOPE-SP-CL Multidimensional symptom and problem checklist, SAS Symptom Assessment Scale, FACT-G Functional Assessment of Cancer Therapy- General. ${ }^{1}$ IsiZulu (49.6\%), English (15.3\%), isiXhosa (12.8\%), Luganda (6.4\%), SeSotho (6.3\%), Runyoro (5.4\%), Runyankole (3.9\%), and SeTswana (0.4\%). 7 for the patients and 3 for the caregivers. 


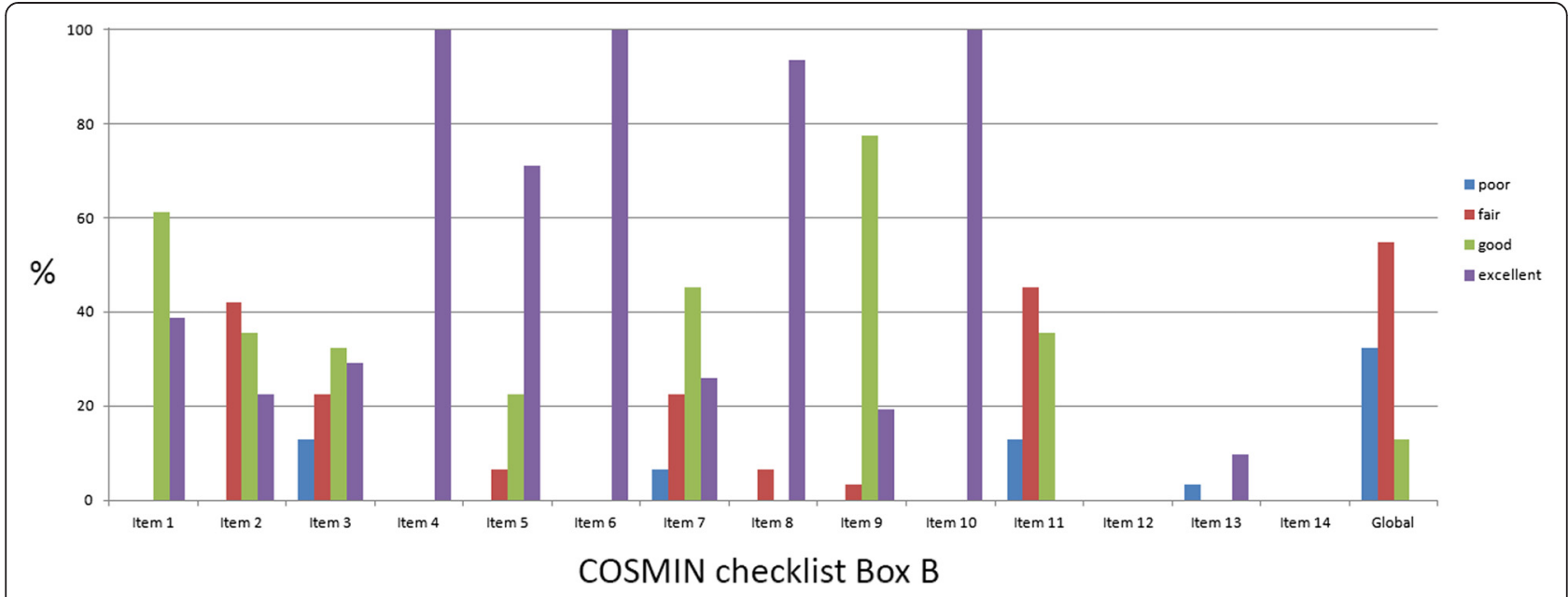

Figure 2 Quality criteria of the included studies according to the COSMIN checklist.

studies, we hypothesize that researchers are not systematically measuring it because of the instability of advanced cancer patients. Overall, half of the evaluated test-retest reliability scores were classified as inadequate when 0.70 was used as the threshold value [9]. The pressure experienced by scientific researchers to publish positive results [41] may also explain why only $34.8 \%$ of validation studies measured the test-retest reliability. Furthermore, it is possible that inappropriate test-retest values were omitted from some publications.

It is essential to accurately estimate the sample size prior to beginning a study. An insufficient sample size might not detect true differences, which might lead to unreliable results. Conversely, an excessive sample size may produce unnecessary financial losses and ethical concerns regarding futile exposure of study participants [42]. With regards to test-retest reliability analysis, we observed that determining an adequate sample size is not a common practice because only 2 studies [28,37] described performing a sample size calculation prior to

Table 2 Association between the test-retest reliability values and the evidence of clinical stability

\begin{tabular}{|c|c|c|c|c|c|}
\hline \multirow[t]{3}{*}{ Test-retest values } & \multicolumn{4}{|c|}{$\begin{array}{l}\text { Were patients stable in } \\
\text { the interim period on the } \\
\text { construct to be measured? }\end{array}$} & \multirow[t]{3}{*}{$P^{*}$} \\
\hline & Poor & Fair & Good & Excellent & \\
\hline & N (\%) & N (\%) & N (\%) & $\mathrm{N}(\%)$ & \\
\hline Global HRQoL scores & & & & & 0.015 \\
\hline$<0.70$ & $2(18.2)$ & $5(45.5)$ & $4(36.4)$ & $0(0)$ & \\
\hline$\geq 0.70$ & $0(0)$ & $1(12.5)$ & $5(62.5)$ & $2(25.0)$ & \\
\hline Pain scores & & & & & 0.031 \\
\hline$<0.70$ & $2(18.2)$ & $3(27.3)$ & $3(27.3)$ & $1(9.1)$ & \\
\hline$\geq 0.70$ & $0(0)$ & $1(11.1)$ & $4(44.4)$ & $4(44.4)$ & \\
\hline
\end{tabular}

$H R Q o L$ health-related quality of life.

*p-value for linear trend. the study. Overall, the median number of included patients for test-retest analysis was 60, which represents $53.8 \%$ of the total number of included patients. One study [35] justified the sample size by citing a rule of thumb suggesting that 50 patients would be sufficient for the analysis $[43,44]$.

A basic concept regarding test-retest reliability is the need to retest clinically stable patients [45]. The retest of advanced cancer patients is challenging because they are in a dynamic phase of their disease in which symptoms and functionality are prone to decline quickly. The retest of a clinically unstable patient may incorrectly define a PRO as a non-reliable tool. Our results confirm the importance of verifying the clinical stability of the patients before retesting. In addition, our review

Table 3 Number of studies with adequate and nonadequate test-retest values

\begin{tabular}{lccc}
\hline $\begin{array}{l}\text { Evaluated } \\
\text { domains }\end{array}$ & $\begin{array}{c}\text { Number } \\
\text { of studies }\end{array}$ & \multicolumn{2}{c}{ Test-retest values } \\
\cline { 3 - 4 } & 19 & $\mathbf{2 0 . 7 0}$ & $\mathbf{2 0 . 7 0}$ \\
\hline Global HRQoL & 8 & $\mathbf{n}(\%)$ \\
Emotional & 5 & $1(12.5)$ & $8(42.1)$ \\
Physical & 6 & $1(20)$ & $7(87.5)$ \\
Social & 3 & $2(33.3)$ & $4(80)$ \\
Functioning & 6 & $0(0)$ & $4(66.7)$ \\
Existential & 5 & $1(16.7)$ & $3(100)$ \\
Global symptoms & 18 & $2(40)$ & $3(83.3)$ \\
Pain & 12 & $9(50)$ & $9(50)$ \\
Nausea & 11 & $5(41.6)$ & $7(58.3)$ \\
Fatigue & 10 & $6(54.5)$ & $5(45.5)$ \\
Anxiety & 9 & $6(60)$ & $4(40)$ \\
Depression & $4(44.4)$ & $5(55.6)$ \\
\hline
\end{tabular}

HRQoL health-related quality of life. 
Table 4 Median values of time intervals of studies with non-adequate $(<0.70)$ and adequate $(\geq 0.70)$ test-retest values

\begin{tabular}{lcccc}
\hline $\begin{array}{l}\text { Evaluated } \\
\text { domains }\end{array}$ & $\begin{array}{c}\text { Number } \\
\text { of studies }\end{array}$ & \multicolumn{2}{c}{$\begin{array}{c}\text { Time interval (hours) } \\
\text { Median (Q1-Q3) }\end{array}$} & p-value* \\
\cline { 2 - 4 } & & $\begin{array}{c}\text { Test-retest } \\
<\mathbf{0 . 7 0}\end{array}$ & $\begin{array}{c}\text { Test-retest } \\
\mathbf{2 0 . 7 0}\end{array}$ & \\
\hline Global HRQoL & 19 & $168(36-168)$ & $60(36.75-206)$ & 0.565 \\
Emotional & 8 & $168^{1}$ & $168(48-204)$ & - \\
Physical & 5 & $168^{1}$ & $108(30-195)$ & - \\
Social & 6 & $186^{2}$ & $108(48-195)$ & - \\
Functioning & 3 & - & $168^{3}$ & - \\
Existential & 6 & $120^{1}$ & $168(48-232)$ & - \\
Global symptoms & 5 & $25.75^{2}$ & $48^{3}$ & - \\
Pain & 18 & $120(42-168)$ & $48(3-168)$ & 0.262 \\
Nausea & 12 & $108(33-168)$ & $24(3-72)$ & 0.146 \\
Fatigue & 11 & $48(24-168)$ & $3(2.5-120)$ & 0.184 \\
Anxiety & 10 & $72(36-168)$ & $48(8.25-144)$ & 0.443 \\
Depression & 9 & $102(27-168)$ & $60(18.75-96)$ & 0.587 \\
\hline
\end{tabular}

HRQoL health-related quality of life.

*Mann-Whitney test.

'Only one study. ${ }^{2}$ Only two studies. ${ }^{3}$ Only three studies.

described the objective criteria used by some studies to define a stable condition.

The definition of an adequate between-assessment time gap for the retest is of the utmost importance. An insufficient time period might allow respondents to recall their first answers, and a longer interval might allow for a true change of the construct to occur $[2,45]$. The appropriate time interval depends on the construct to be measured and the target population [46]; however, approximately 2 weeks is often considered generally appropriate [47]. Nevertheless, the time interval over which to retest advanced cancer patients under PC is still a matter of debate. Some authors have considered retesting advanced cancer patients at least 3 days apart as a measure of responsiveness but not as a measure of test-retest reliability [4].

In fact, because of concerns about reassessing an unstable patient, some authors $(n=7)$ reapplied the questionnaires at very short intervals (i.e., less than 24 hours). Jim et al. [48] investigated daily and intraday changes in the fatigue, depression, sleep, and activity scores in a cohort of cancer patients undergoing chemotherapy. Significant changes were observed over time. Additionally, Dimsdale et al. [49] investigated cancer-related fatigue every hour for 72 consecutive hours and observed a diurnal variation in fatigue. HRQoL, on the other hand, is a multidimensional construct that encompass physical, psychological, social, and spiritual domains. In general, instruments that measure HRQoL use recall periods of 7 days. Although HRQoL is not commonly assessed on a daily basis, it is expected to behave stably over a few days, especially the social, existential, and global domains. Consequently, we observed that multi-symptom instruments are generally retested within a shorter time frame than HRQoL instruments.

There was a trend of shorter time periods in the adequate test-retest reliability results when compared with the scores with inadequate results (less than 0.7). One reason contributing to the non-significant results might be the large interquartile range for some of the domains; since few studies were analyzed, there was insufficient statistical power for further conclusions. Three studies $[18,29,40]$ evaluated the retest reliability at 2 different time points $(<24$ hours and 1 week after the first evaluation); in general, a lower time interval was associated with a better retest analysis result. Considering the median time interval used in the studies with adequate testretest results, in addition to the findings from studies that used two different time intervals for the retest, we can recommend that patients under palliative care for advanced cancer should be retested somewhere around 24 to 48 hours later when evaluating cancer symptoms and 2 to 7 days later when assessing HRQoL. However, we believe that the most important factor is not the time itself but rather confirmation of clinical stability before retesting patients.

As mentioned previously, we concluded that the testretest reliability analysis was of low quality according to the COSMIN checklist. Other studies using the same guidelines but not the same population have yielded similar results [50-52]. The most troublesome question

Table 5 Test-retest reliability scores measured at two different time intervals from the first evaluation

\begin{tabular}{|c|c|c|c|c|c|c|c|}
\hline \multirow[t]{2}{*}{ Author (year) } & \multirow{2}{*}{$\begin{array}{l}\text { Time to } \\
\text { retest }\end{array}$} & \multicolumn{6}{|c|}{ Scores } \\
\hline & & Global HRQoL & Pain & Nausea & Fatigue & Anxiety & Depression \\
\hline \multirow[t]{2}{*}{ Kim et al. [18] } & 3 hours & 0.93 & $\mathrm{NA}$ & NA & NA & NA & NA \\
\hline & 7 days & 0.63 & NA & NA & NA & NA & NA \\
\hline \multirow[t]{2}{*}{ Chang et al. [29] } & 24 hours & NA & 0.79 & 0.58 & 0.39 & 0.62 & 0.81 \\
\hline & 7 days & NA & 0.75 & 0.31 & 0.65 & 0.35 & 0.54 \\
\hline \multirow[t]{2}{*}{ Sterkenburg et al. [40] } & 3 hours & 0.84 & NA & NA & NA & NA & NA \\
\hline & 7 days & 0.63 & NA & NA & NA & NA & NA \\
\hline
\end{tabular}

NA not evaluated. 
in our review was item 11 ("for continuous scores: was an intraclass correlation coefficient calculated?"), with $62 \%$ of studies classified as poor to fair quality. The preferred test-retest reliability statistic depends on the type of response options. In our review, the majority of the studies evaluated continuous scores. In these cases, the ICC [31] is the preferred statistic $[46,47,53]$. Moreover, the use of correlation coefficients (Pearson's and Spearman's tests) is not adequate because they do not include a consideration of systematic error [46]. In the present study, 18 of 29 studies evaluating continuous scores used a correlation analysis, but they did not evaluate the agreement by using the ICC. Six different versions of ICC can be used depending on various assumptions, and 4 of those are subdivided into consistency or absolute agreement, yielding a total of 10 different ICC calculations [54]. The choice of the correct index has a highly significant impact on the numerical value of the ICC [53]. Even in those studies that correctly used the ICC, none stated the version of the ICC used.

This study has some limitations. Because the studies evaluated test-retest reliability using different statistics, we could not perform a robust meta-analysis. Therefore, we decided to use 0.7 as the threshold for adequate results on test-retest reliability to perform a pooled data analysis. However, the categorization of the test-retest results as a function of a predefined cut-off point may be considered an inadequate simplification. Another limitation is that we did not include in the systematic review other instruments developed to assess only one symptom (fatigue or pain scales, for example). In addition, we did not include abstracts from meetings because it would be difficult to extract the necessary data.

\section{Conclusions}

In conclusion, we determined that test-retest reliability has been infrequently and poorly evaluated in validation studies of PRO assessing advanced cancer patients under PC. Multi-symptom instruments were retested over a shorter time interval when compared to HRQoL. The confirmation of clinical stability was an important factor in our analysis, and we suggest that special attention to this parameter is required when designing a PRO validation study that includes advanced cancer patients under PC.

\section{Competing interests}

The authors declare that they have no competing interests.

\section{Authors' contributions}

CEP and BSRP conceived the study. CPS and FT identified the studies. CEP, CPS, and BSRP extracted the data. CEP and EMB evaluated the quality of the studies according to the COSMIN checklist. CEP and ECC performed the analyses. CEP, ECC, RVML, EMB, and BSRP drafted the manuscript. All authors read and approved the final manuscript.

\section{Author details}

'Department of Clinical Oncology, Barretos Cancer Hospital, Barretos, São Paulo CEP 14784-400, Brazil. ²Palliative Care and Quality of Life Research Group, Post-Graduate Program, Barretos Cancer Hospital, Barretos, São Paulo, Brazil. ${ }^{3}$ Researcher Support Center, Learning and Research Institute, Barretos Cancer Hospital, Barretos, São Paulo, Brazil.

Received: 24 September 2013 Accepted: 13 January 2014

Published: 21 January 2014

\section{References}

1. Ferrell B, Paice J, Koczywas M: New standards and implications for improving the quality of supportive oncology practice. J Clin Oncol 2008, 26(23):3824-3831.

2. Frost MH, Reeve BB, Liepa AM, Stauffer JW, Hays RD, Mayo FDAP-ROCMG: What is sufficient evidence for the reliability and validity of patientreported outcome measures? Value Health 2007, 10(Suppl 2):S94-S105.

3. Aaronson N, Alonso J, Burnam A, Lohr KN, Patrick DL, Perrin E, Stein RE: Assessing health status and quality-of-life instruments: attributes and review criteria. Qual Life Res 2002, 11(3):193-205.

4. Richardson LA, Jones GW: A review of the reliability and validity of the Edmonton Symptom Assessment System. Curr Oncol 2009, 16(1):55.

5. The Patient-Reported Outcome and Quality of Life Instrument Database (PROQOLID). http://www.proqolid.org/.

6. Australian Centre on Quality of Life (ACQOL). http://www.deakin.edu.au/ research/acqol/index.php.

7. Mokkink LB, Terwee CB, Patrick DL, Alonso J, Stratford PW, Knol DL, Bouter LM, de Vet HC: The COSMIN checklist for assessing the methodological quality of studies on measurement properties of health status measurement instruments: an international Delphi study. Qual Life Res 2010, 19(4):539-549.

8. Terwee CB, Mokkink LB, Knol DL, Ostelo RW, Bouter LM, de Vet HC: Rating the methodological quality in systematic reviews of studies on measurement properties: a scoring system for the COSMIN checklist. Qual Life Res 2012, 21(4):651-657.

9. Terwee CB, Bot SD, de Boer MR, van der Windt DA, Knol DL, Dekker J, Bouter LM, de Vet HC: Quality criteria were proposed for measurement properties of health status questionnaires. J Clin Epidemiol 2007, 60(1):34-42.

10. Axelsson B, Sjoden PO: Assessment of quality of life in palliative care-psychometric properties of a short questionnaire. Acta Oncol 1999, 38(2):229-237.

11. Cohen SR, Mount BM: Living with cancer: "good" days and "bad" days-what produces them? Can the McGill quality of life questionnaire distinguish between them? Cancer 2000, 89(8):1854-1865.

12. Llobera J, Esteva M, Benito E, Terrasa J, Rifa J, Pons O, Maya A: Quality of life for oncology patients during the terminal period. Validation of the HRCA-QL index. Support Care Cancer 2003, 11(5):294-303.

13. Mystakidou K, Tsilika E, Kouloulias V, Parpa E, Katsouda E, Kouvaris J, Vlahos $L$ : The "Palliative Care Quality of Life Instrument (PQLI)" in terminal cancer patients. Health Qual Life Outcomes 2004, 2:8.

14. Steinhauser KE, Clipp EC, Bosworth HB, McNeilly M, Christakis NA, Voils Cl, Tulsky JA: Measuring quality of life at the end of life: validation of the QUAL-E. Palliat Support Care 2004, 2(1):3-14

15. Lopes Ferreira $P$, Pinto Barros $A$ : Measuring quality of life in palliative care. Acta Med Port 2008, 21(2):111-124.

16. Suarez-del-Real $Y$, Allende-Perez S, Alferez-Mancera A, Rodriguez RB, Jimenez-Toxtle S, Mohar A, Onate-Ocana LF: Validation of the MexicanSpanish version of the EORTC QLQ-C15-PAL questionnaire for the evaluation of health-related quality of life in patients on palliative care. Psychooncology 2011, 20(8):889-896.

17. Leppert W, Majkowicz M: Validation of the Polish version of the European Organization for Research and Treatment of Cancer Quality of Life Questionnaire - Core 15 - Palliative Care in patients with advanced cancer. Palliat Med 2013, 27(5):470-477.

18. Kim KU, Yoon SJ, Lee JL, Ahn HS, Park HJ, Lee SI, Jo MW: Validation of the Korean version of the McMaster Quality of Life Scale in terminal cancer patients. J Palliat Care 2006, 22(1):40-45

19. Kim SH, Choi YS, Lee J, Oh SC, Yeom CH, Lee MA, Kim DG, Moon Do H, Kim DY, Koh SJ: Reliability and validity of the Hospice Quality of Life Scale for Korean cancer patients. J Pain Symptom Manage 2009, 37(2):156-167. 
20. Serra-Prat M, Nabal M, Santacruz V, Picaza JM, Trelis J, Grupo Catalan de Estudio de la Efectividad de los Cuidados P: Validation of the Spanish version of the palliative care outcome scale. Med Clin 2004, 123(11):406-412.

21. Eisenchlas JH, Harding R, Daud ML, Perez M, De Simone GG, Higginson IJ: Use of the palliative outcome scale in Argentina: a cross-cultural adaptation and validation study. J Pain Symptom Manage 2008, 35(2):188-202.

22. Guo H, Fine PG, Mendoza TR, Cleeland CS: A preliminary study of the utility of the brief hospice inventory. J Pain Symptom Manage 2001, 22(2):637-648

23. Lo RS, Woo J, Zhoc KC, Li CY, Yeo W, Johnson P, Mak Y, Lee J: Cross-cultural validation of the McGill Quality of Life questionnaire in Hong Kong Chinese Palliat Med 2001, 15(5):387-397.

24. Shahidi J, Khodabakhshi R, Gohari MR, Yahyazadeh H, Shahidi N: McGill Quality of Life Questionnaire: reliability and validity of the Persian version in Iranian patients with advanced cancer. J Palliat Med 2008 11(4):621-626

25. Harding R, Selman L, Agupio G, Dinat N, Downing J, Gwyther L, Mashao T, Mmoledi K, Moll T, Sebuyira LM, et al: Validation of a core outcome measure for palliative care in Africa: the APCA African Palliative Outcome Scale. Health Qual Life Outcomes 2010, 8:10.

26. Hearn J, Higginson IJ: Development and validation of a core outcome measure for palliative care: the palliative care outcome scale. Palliative Care Core Audit Project Advisory Group. Qual Health Care 1999, 8(4):219-227.

27. Wilson KG, Graham ID, Viola RA, Chater S, de Faye BJ, Weaver LA, Lachance $J A$ : Structured interview assessment of symptoms and concerns in palliative care. Can J Psychiatry 2004, 49(6):350-358.

28. Agra Y, Badia X: Spanish version of the Rotterdam Symptom Check List: cross-cultural adaptation and preliminary validity in a sample of terminal cancer patients. Psychooncology 1998, 7(3):229-239.

29. Chang VT, Hwang SS, Feuerman M: Validation of the Edmonton Symptom Assessment Scale. Cancer 2000, 88(9):2164-2171.

30. Stiel S, Matthes ME, Bertram L, Ostgathe C, Elsner F, Radbruch L: Validation of the new version of the minimal documentation system (MIDOS) for patients in palliative care : the German version of the edmonton symptom assessment scale (ESAS). Schmerz 2010, 24(6):596-604.

31. Moro C, Brunelli C, Miccinesi G, Fallai M, Morino P, Piazza M, Labianca R, Ripamonti C: Edmonton symptom assessment scale: Italian validation in two palliative care settings. Support Care Cancer 2006, 14(1):30-37.

32. Mystakidou K, Cleeland C, Tsilika E, Katsouda E, Primikiri A, Parpa E, Vlahos L, Mendoza T: Greek M.D. Anderson symptom inventory: validation and utility in cancer patients. Oncology 2004, 67(3-4):203-210.

33. Pautex S, Berger A, Chatelain C, Herrmann F, Zulian GB: Symptom assessment in elderly cancer patients receiving palliative care. Crit Rev Oncol Hematol 2003, 47(3):281-286

34. Stiel S, Pollok A, Elsner F, Lindena G, Ostgathe C, Nauck F, Radbruch L: Validation of the symptom and problem checklist of the German Hospice and Palliative Care Evaluation (HOPE). J Pain Symptom Manage 2012, 43(3):593-605.

35. Carvajal A, Centeno C, Watson R, Bruera E: A comprehensive study of psychometric properties of the Edmonton Symptom Assessment System (ESAS) in Spanish advanced cancer patients. Eur J Cancer 2011, 47(12):1863-1872.

36. Radbruch L, Sabatowski R, Loick G, Jonen-Thielemann I, Elsner F, Hormann E: MIDOS-validation of a minimal documentation system for palliative medicine. Schmerz 2000, 14(4):231-239.

37. Kwon JH, Nam SH, Koh S, Hong YS, Lee KH, Shin SW, Hui D, Park KW, Yoon SY, Won JY, et al: Validation of edmonton symptom assessment system in korean patients with cancer. J Pain Symptom Manage 2013, 46(6):947-956.

38. Aoun SM, Monterosso L, Kristjanson LJ, McConigley R: Measuring symptom distress in palliative care: psychometric properties of the Symptom Assessment Scale (SAS). J Palliat Med 2011, 14(3):315-321.

39. Pereira F, Santos C: Estudo de adaptação cultural e validação da Functional Assessment of Cancer Therapy-General em cuidados paliativos. Rev Enferm Referênci 2011, 5:10.

40. Sterkenburg CA, King B, Woodward CA: A reliability and validity study of the McMaster Quality of Life Scale (MQLS) for a palliative population. J Palliat Care 1996, 12(1):18-25.

41. Fanelli D: Do pressures to publish increase scientists' bias? An empirical support from US States Data. PLoS One 2010, 5(4):e10271.
42. Guo $Y$, Logan HL, Glueck DH, Muller KE: Selecting a sample size for studies with repeated measures. BMC Med Res Methodol 2013, 13:100.

43. Hopkins WG: Measures of reliability in sports medicine and science. Sports Med 2000, 30(1):1-15.

44. Atkinson G, Nevill A: Typical error versus limits of agreement. Sports Med 2000, 30(5):375-381.

45. Fayers P, Machin D: Quality of Life. Assessment, Analysis and Interpretation. 2nd edition. Chichester: John Wiley; 2007.

46. The COSMIN checklist manual. http://www.cosmin.nl.

47. Streiner DL, Norman GR: Health Measurement Scales. A Practical Guide to Their Development and use. 4th edition. New York: Oxford University Press; 2008.

48. Jim HS, Small B, Faul LA, Franzen J, Apte S, Jacobsen PB: Fatigue, depression, sleep, and activity during chemotherapy: daily and intraday variation and relationships among symptom changes. Ann Behav Med 2011, 42(3):321-333.

49. Dimsdale JE, Ancoli-Israel S, Ayalon L, Elsmore TF, Gruen W: Taking fatigue seriously, II: variability in fatigue levels in cancer patients. Psychosomatics 2007, 48(3):247-252.

50. Vrijman C, Homan ML, Limpens J, van der Veen W, Wolkerstorfer A, Terwee CB, Spuls PI: Measurement properties of outcome measures for Vitiligo: a systematic review. Arch Dermatol 2012, 148(11):1302-1309.

51. Abma Fl, van der Klink JJ, Terwee CB, Amick BC 3rd, Bultmann U: Evaluation of the measurement properties of self-reported health-related work-functioning instruments among workers with common mental disorders. Scand J Work Environ Health 2012, 38(1):5-18.

52. Reimers AK, Mess F, Bucksch J, Jekauc D, Woll A: Systematic review on measurement properties of questionnaires assessing the neighbourhood environment in the context of youth physical activity behaviour. BMC Public Health 2013, 13:461.

53. Werner MU, Petersen MA, Bischoff JM: Test-retest studies in quantitative sensory testing: a critical review. Acta Anaestheriol Scand 2013, 57(8):957-963

54. Shrout PE, Fleiss JL: Intraclass correlations: uses in assessing rater reliability. Psychol Bull 1979, 86(2):420-428.

doi:10.1186/1471-2288-14-8

Cite this article as: Paiva et al:: A critical analysis of test-retest reliability in instrument validation studies of cancer patients under palliative care: a systematic review. BMC Medical Research Methodology 2014 14:8.

\section{Submit your next manuscript to BioMed Central and take full advantage of:}

- Convenient online submission

- Thorough peer review

- No space constraints or color figure charges

- Immediate publication on acceptance

- Inclusion in PubMed, CAS, Scopus and Google Scholar

- Research which is freely available for redistribution 